Article

\title{
The Acute Toxicity and Hematological Characterization of the Effects of Tentacle-Only Extract from the Jellyfish Cyanea capillata
}

\section{Liang Xiao ${ }^{1, \dagger}$, Sihua Liu ${ }^{1, \dagger}$, Qian He ${ }^{2, \dagger}$, Qianqian Wang ${ }^{1}$, Xuting Ye ${ }^{3}$, Guoyan Liu ${ }^{1}$, Fei Nie ${ }^{1}$, Jie Zhao ${ }^{1, *}$ and Liming Zhang ${ }^{1, *}$}

1 Department of Chemical Defense Medicine, Faculty of Naval Medicine, Second Military Medical University, Shanghai 200433, China; E-Mails: xiaoliang830713@ sohu.com (L.X.); langer1013@126.com (S.L.); abc_w@163.com (Q.W.); lgy_laurie@yahoo.com.cn (G.L.); niefei527@126.com (F.N.)

2 Department of Gynecology and Obstetrics, Shanghai Hospital, Second Military Medical University, Shanghai 200433, China; E-Mail: cpulj@126.com

3 Department of Biophysics, School of Basic Medical, Second Military Medical University, Shanghai 200433, China; E-Mail: xuting_3@ hotmail.com

$\dagger$ These authors contributed equally to the work.

* Authors to whom correspondence should be addressed; E-Mails: zs1010@ hotmail.com (J.Z.); lmzhang1969@yahoo.com.cn (L.Z.); Tel./Fax: +86-21-8187-1128 (L.Z.).

Received: 13 February 2011; in revised form: 14 March 2011 / Accepted: 25 March 2011 / Published: 29 March 2011

\begin{abstract}
To investigate the hematologic changes and the activities of jellyfish venoms other than hemolytic and cardiovascular toxicities, the acute toxicity of tentacle-only extract (TOE) from the jellyfish Cyanea capillata was observed in mice, and hematological indexes were examined in rats. The median lethal dose $\left(\mathrm{LD}_{50}\right)$ of TOE was $4.25 \mathrm{mg} / \mathrm{kg}$, and the acute toxicity involved both heart- and nervous system-related symptoms. Arterial blood gas indexes, including $\mathrm{pH}, \mathrm{PCO}_{2}, \mathrm{HCO}_{3}{ }^{-}, \mathrm{HCO}_{3}$ std, $\mathrm{TCO}_{2}$, BEecf and $\mathrm{BE}(\mathrm{B})$, decreased significantly. $\mathrm{PO}_{2}$ showed a slight increase, while $\mathrm{SO}_{2} \mathrm{c}(\%)$ had no change at any time. $\mathrm{Na}^{+}$and $\mathrm{Ca}^{2+}$ decreased, but $\mathrm{K}^{+}$increased. Biochemical indexes, including $\mathrm{LDH}, \mathrm{CK}$, CK-MB, ALT, AST and sCr, significantly increased. Other biochemical indexes, including BUN and hemodiastase, remained normal. Lactic acid significantly increased, while glucose, $\mathrm{Hct} \%$ and $\mathrm{THbc}$ showed slight temporary increases and then returned to normal. These results on the acute toxicity and hematological changes should improve our understanding of the in vivo pathophysiological effects of TOE from C. capillata and indicate that it may also
\end{abstract}


have neurotoxicity, liver toxicity and muscular toxicity in addition to hemolytic and cardiovascular toxicities, but no kidney or pancreatic toxicity.

Keywords: jellyfish; Cyanea capillata; tentacle-only extract; $\mathrm{LD}_{50}$; toxic symptom; hematological

\section{Introduction}

Jellyfish may be the most common of the medically significant venomous marine creatures, especially in the tropic and subtropic regions. Jellyfish envenomation results in both local reactions (pain and red linear or hive-like lesions) and systemic reactions (nausea, vomiting, muscle cramps, diarrhea, dizziness, diaphoresis, coma, muscular spasms or even death) [1,2]. When human or animal victims contact jellyfish tentacles, the nematocyst threads will launch into their integument and inject venoms composed of multiple proteinaceous toxins into the victim's body, leading to a variety of clinical symptoms, as mentioned above. Jellyfish venoms have a wide spectrum of biological activities, such as hemolytic, enzymatic, dermonecrotic, myotoxic, neurotoxic and cardiovascular toxic effects [2-4], among which the hemolytic and cardiovascular toxicities are the best studied, while the other activities are seldom mentioned. However, much about jellyfish venoms is still unknown.

We have previously found that the tentacle-only extract free of nematocysts (TOE) from the jellyfish Cyanea capillata showed similar hemolytic and cardiovascular toxicities to those of nematocyst venom [5-7]. Further studies have confirmed that cardiotoxicity is the main reason for death caused by TOE in rats [8], and hemolytic toxicity may act in synergy with the cardiovascular effects of TOE by inducing the release of $\mathrm{K}^{+}$and lactic acid from the lysed erythrocytes [9]. Thus, in the present study, we adopted TOE from $C$. capillata as an abundant venom resource to survey the hematologic changes that occur in jellyfish envenomation and investigate the activities of jellyfish venom other than hemolytic and cardiovascular toxicities.

\section{Results}

\section{1. $L D_{50}$ Determination and Toxic Symptoms}

The $\mathrm{LD}_{50}$ of $\mathrm{TOE}$ was $4.25 \mathrm{mg}$ toxin/kg body weight in Kunming mice by tail vein injection (Figure 1), and the toxic symptoms of the mice depended on the TOE dose (Table 1). At the lower doses (less than $5 \mathrm{mg} / \mathrm{kg}$ i.v.), the mice showed progressive malaise, slowness, crouching and weakness, but little change in breathing. Death mainly occurred within $48 \mathrm{~h}$, and if the mice did not die within $48 \mathrm{~h}$, they gradually returned to normal. Autopsy clearly showed heart enlargement and edema and lung edema and congestion with a bright red surface. At intermediate doses (5-10 mg/kg i.v.), deep and fast breathing was observed initially, and then breathing weakened gradually before finally arresting. Additionally, progressive malaise, slowness, crouching, muscle trembling and some double leg twitching were also observed, and most mice died within $2 \mathrm{~h}$. At the higher doses (more than $10 \mathrm{mg} / \mathrm{kg}$ i.v.), deep and fast breathing occurred rapidly, and the mice also showed rapidly progressive whole-body trembling, double leg twitching, convulsion, opisthotonos and death. Most mice died within 
$5 \mathrm{~min}$, and all of the mice died within $15 \mathrm{~min}$. However, both the heart and lung were mostly normal on autopsy.

Figure 1. $\mathrm{LD}_{50}$ determination by tail vein injection in mice. The $\mathrm{LD}_{50}$ is $4.25 \mathrm{mg} / \mathrm{kg}$ for Kunming mice by tail vein injection $(n=12)$.

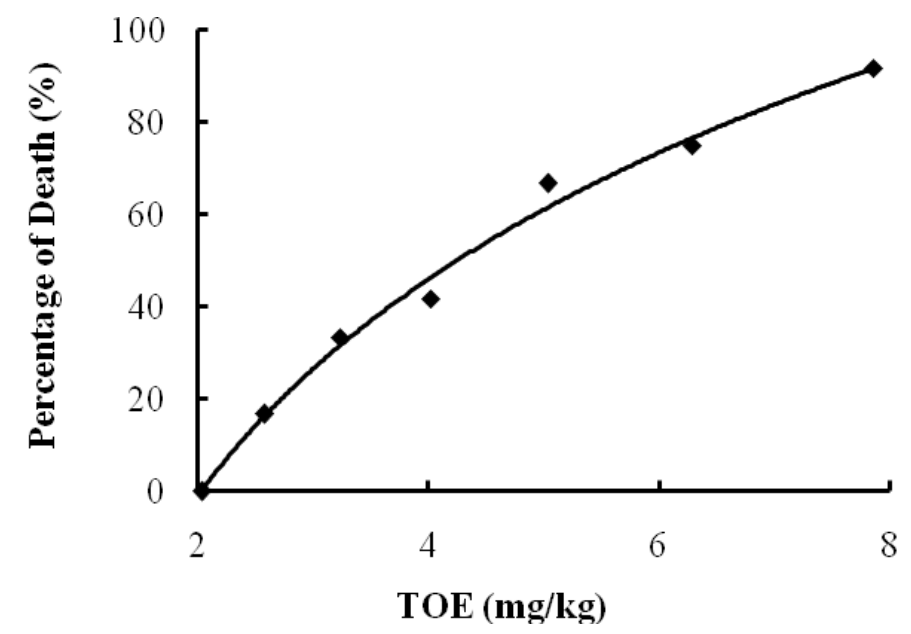

Table 1. Clinical manifestations after administration of tentacle-only extract (TOE) from the jellyfish C. capillata in mice.

\begin{tabular}{|c|c|c|c|c|}
\hline \multirow{2}{*}{ TOE } & \multirow{2}{*}{ Symptoms } & \multirow{2}{*}{ Time to death } & \multicolumn{2}{|r|}{ Autopsy } \\
\hline & & & Heart & Lung \\
\hline$<5 \mathrm{mg} / \mathrm{kg}$ & $\begin{array}{l}\text { Little change in breathing. Progressive } \\
\text { malaise, slowness, crouching and weakness }\end{array}$ & $\begin{array}{l}\text { Mainly within } \\
48 \mathrm{~h}\end{array}$ & $\begin{array}{l}\text { Enlarged, } \\
\text { edema }\end{array}$ & $\begin{array}{l}\text { Bright red, edema } \\
\text { and congestion }\end{array}$ \\
\hline $5-10 \mathrm{mg} / \mathrm{kg}$ & $\begin{array}{l}\text { Early breathing deep and fast, gradually } \\
\text { weakened, and finally arrested. Progressive } \\
\text { malaise, slowness, crouching, muscle } \\
\text { trembling and some double leg twitching }\end{array}$ & $\begin{array}{l}\text { Mainly within } \\
2 \mathrm{~h}\end{array}$ & $\begin{array}{l}\text { Enlarged, } \\
\text { edema }\end{array}$ & $\begin{array}{l}\text { Edema, some } \\
\text { congestion }\end{array}$ \\
\hline$>10 \mathrm{mg} / \mathrm{kg}$ & $\begin{array}{l}\text { Rapid emergence of breathing deep and fast. } \\
\text { Progressive body trembling, double leg } \\
\text { twitching, convulsion, opisthotonos and death }\end{array}$ & $\begin{array}{l}\text { Mainly within } \\
5 \text { min, all } \\
\text { within } 15 \mathrm{~min}\end{array}$ & Normal & Normal \\
\hline
\end{tabular}

\subsection{Effects of TOE on Arterial Blood Gas Indexes}

TOE (5 mg/kg i.v.) produced significant effects on arterial blood gas indexes in anesthetized Sprague-Dawley (SD) rats. The $\mathrm{pH}$ and $\mathrm{PCO}_{2}$ dropped, while $\mathrm{PO}_{2}$ increased, and $\mathrm{SO}_{2} \mathrm{c}(\%)$ was not obviously changed within $180 \mathrm{~min}$ after TOE injection. Other blood gas indexes, including $\mathrm{HCO}_{3}{ }^{-}$, $\mathrm{HCO}_{3}$ std, $\mathrm{TCO}_{2}$, BEecf and $\mathrm{BE}(\mathrm{B})$, all decreased significantly within 5 min after TOE administration (Table 2).

\subsection{Effects of TOE on Other Blood Indexes Determined by the Blood Gas Analyzer}

The electrolytes $\mathrm{Na}^{+}, \mathrm{K}^{+}$and $\mathrm{Ca}^{2+}$ were all significantly influenced by TOE $(5 \mathrm{mg} / \mathrm{kg}$ i.v.). $\mathrm{Na}^{+}$rapidly decreased and did not recover within $180 \mathrm{~min} . \mathrm{K}^{+}$rapidly increased, with a maximum at $5 \mathrm{~min}(11.7 \pm 1.9 \mathrm{mmol} / \mathrm{L})$, then partially recovered. $\mathrm{Ca}^{2+}$ rapidly decreased and reached a minimum at 
$10 \mathrm{~min}(0.78 \pm 0.16 \mathrm{mmol} / \mathrm{L})$, then increased to $1.26 \pm 0.05 \mathrm{mmol} / \mathrm{L}$ at $180 \mathrm{~min}$. Similar results were obtained for the standard $\mathrm{Ca}^{2+}$, which was adjusted at $\mathrm{pH} 7.4$ (Table 3 ).

After TOE administration ( $5 \mathrm{mg} / \mathrm{kg}$ i.v.), Glu increased and reached a maximum $(11.4 \pm 3.2 \mathrm{mmol} / \mathrm{L})$ within $20 \mathrm{~min}$, then gradually dropped to normal. Lac significantly increased and reached a maximum at $10 \mathrm{~min}(5.9 \pm 0.9 \mathrm{mmol} / \mathrm{L})$, then partially recovered. Both Hct\% and $\mathrm{THbc}$ increased and reached a maximum at $10 \mathrm{~min}(53 \pm 4 \%$ and $16.3 \pm 1.2 \mathrm{~g} / \mathrm{dL}$, respectively), then dropped to normal (Table 3$)$.

Table 2. Effects of TOE from the jellyfish $C$. capillata on arterial blood gas indexes in anesthetized SD rats. Data are presented as means \pm SD $(n=6, * P<0.05$, ** $P<0.01 v s$. 0 min).

\begin{tabular}{cccccccccc}
\hline \multicolumn{9}{c}{ Direct indexes } \\
\hline & $\mathbf{p H}$ & $\begin{array}{c}\mathbf{P C O} \\
(\mathbf{m m H g})\end{array}$ & $\begin{array}{c}\mathbf{P O}_{\mathbf{2}} \\
(\mathbf{m m H g})\end{array}$ & $\begin{array}{c}\mathbf{H C O}_{\mathbf{3}}{ }^{-} \\
(\mathbf{m m o l} / \mathbf{L})\end{array}$ & $\begin{array}{c}\mathbf{H C O}_{3} \mathbf{s t d} \\
(\mathbf{m m o l} / \mathbf{L})\end{array}$ & $\begin{array}{c}\mathbf{T C O}_{\mathbf{2}} \\
(\mathbf{m m o l} / \mathbf{L})\end{array}$ & $\begin{array}{c}\mathbf{B E e c f} \\
(\mathbf{m m o l} / \mathbf{L})\end{array}$ & $\begin{array}{c}\mathbf{B E}(\mathbf{B}) \\
(\mathbf{m m o l} / \mathbf{L})\end{array}$ & $\begin{array}{c}\mathbf{S O}_{\mathbf{2}} \mathbf{c} \\
(\boldsymbol{\%})\end{array}$ \\
\hline $0 \mathrm{~min}$ & $7.37 \pm 0.03$ & $48 \pm 4$ & $78 \pm 10$ & $27.5 \pm 3.1$ & $25.9 \pm 2.4$ & $28.9 \pm 3.2$ & $2.1 \pm 3.5$ & $1.4 \pm 3.0$ & $95 \pm 2$ \\
$5 \mathrm{~min}$ & $7.32 \pm 0.07 * *$ & $41 \pm 7 *$ & $88 \pm 12$ & $20.8 \pm 3.3 * *$ & $20.9 \pm 2.7 * *$ & $22.0 \pm 3.4 * *$ & $-5.3 \pm 3.8 * *$ & $-5.1 \pm 3.4 * *$ & $95 \pm 2$ \\
$10 \mathrm{~min}$ & $7.25 \pm 0.05 * *$ & $41 \pm 4 *$ & $93 \pm 4 * *$ & $18.1 \pm 3.2 * *$ & $17.9 \pm 2.7 * *$ & $19.3 \pm 3.3 * *$ & $-9.2 \pm 3.8 * *$ & $-8.9 \pm 3.5 * *$ & $96 \pm 1$ \\
$20 \mathrm{~min}$ & $7.27 \pm 0.06 * *$ & $41 \pm 8 *$ & $87 \pm 8 * *$ & $18.6 \pm 2.6 * *$ & $18.7 \pm 2.0 * *$ & $19.9 \pm 2.8 * *$ & $-8.3 \pm 2.8 * *$ & $-7.9 \pm 2.6 * *$ & $95 \pm 2$ \\
$60 \mathrm{~min}$ & $7.27 \pm 0.05 * *$ & $36 \pm 3 *$ & $89 \pm 11 *$ & $16.5 \pm 2.4 * *$ & $17.3 \pm 2.3 * *$ & $17.5 \pm 2.5 * *$ & $-10.5 \pm 3.1 * *$ & $-9.7 \pm 2.9 * *$ & $95 \pm 2$ \\
$180 \mathrm{~min}$ & $7.28 \pm 0.02 * *$ & $34 \pm 7 * *$ & $91 \pm 11 *$ & $16.6 \pm 3.2 * *$ & $17.6 \pm 1.9 * *$ & $17.7 \pm 3.5 * *$ & $-10.1 \pm 3.1 * *$ & $-9.3 \pm 2.5 * *$ & $94 \pm 4$ \\
\hline
\end{tabular}

Table 3. Effects of TOE from the jellyfish $C$. capillata on blood indexes as measured by an arterial blood gas analyzer in anesthetized SD rats. Data are presented as means $\pm \operatorname{SD}(n=6$, $* P<0.05, * * P<0.01$ vs. $0 \mathrm{~min})$.

\begin{tabular}{ccccccccc}
\hline & $\begin{array}{c}\mathbf{N a}^{+} \\
(\mathbf{m m o l} / \mathbf{L})\end{array}$ & $\mathbf{K}^{+}(\mathbf{m m o l} / \mathbf{L})$ & $\begin{array}{c}\mathbf{C a}^{2+} \\
(\mathbf{m m o l} / \mathbf{L})\end{array}$ & $\begin{array}{c}\mathbf{C a}^{2+}(\mathbf{7 . 4}) \\
(\mathbf{m m o l} / \mathbf{L})\end{array}$ & $\begin{array}{c}\mathbf{G l u} \\
(\mathbf{m m o l} / \mathbf{L})\end{array}$ & $\begin{array}{c}\mathbf{L a c} \\
(\mathbf{m m o l} / \mathbf{L})\end{array}$ & $\begin{array}{c}\text { Hct } \\
(\boldsymbol{\%})\end{array}$ & $\begin{array}{c}\mathbf{T H b c} \\
(\mathbf{g} / \mathbf{d L})\end{array}$ \\
\hline $0 \mathrm{~min}$ & $143 \pm 2$ & $3.6 \pm 0.2$ & $1.18 \pm 0.04$ & $1.17 \pm 0.05$ & $8.1 \pm 1.3$ & $2.7 \pm 0.7$ & $47 \pm 4$ & $14.8 \pm 1.1$ \\
$5 \mathrm{~min}$ & $129 \pm 4 * *$ & $11.7 \pm 1.9 * *$ & $0.82 \pm 0.12 * *$ & $0.79 \pm 0.12 * *$ & $9.3 \pm 2.2$ & $5.1 \pm 0.7 * *$ & $51 \pm 5$ & $15.8 \pm 1.5$ \\
$10 \mathrm{~min}$ & $133 \pm 4 * *$ & $9.7 \pm 2.0 * *$ & $0.78 \pm 0.16 * *$ & $0.73 \pm 0.15 * *$ & $10.0 \pm 2.8$ & $5.9 \pm 0.1 * *$ & $53 \pm 4 *$ & $16.3 \pm 1.2 *$ \\
$20 \mathrm{~min}$ & $134 \pm 3 * *$ & $6.8 \pm 1.1 * *$ & $1.07 \pm 0.17$ & $1.05 \pm 0.14 *$ & $11.0 \pm 2.3 *$ & $5.3 \pm 0.7 * *$ & $52 \pm 5$ & $16.0 \pm 1.4$ \\
$60 \mathrm{~min}$ & $135 \pm 4 * *$ & $5.3 \pm 1.5 * *$ & $1.25 \pm 0.09$ & $1.18 \pm 0.10$ & $10.9 \pm 1.7 * *$ & $4.7 \pm 0.7 * *$ & $49 \pm 3$ & $15.1 \pm 0.7$ \\
$180 \mathrm{~min}$ & $133 \pm 3 * *$ & $6.5 \pm 0.8 * *$ & $1.26 \pm 0.05 * *$ & $1.20 \pm 0.05$ & $9.5 \pm 2.4$ & $4.3 \pm 1.0 * *$ & $46 \pm 4$ & $14.4 \pm 1.3$ \\
\hline
\end{tabular}

\subsection{Effects of TOE on Blood Biochemical Indexes}

After TOE administration (5 mg/kg i.v.), the blood biochemical indexes, including LDH, CK, CK-MB, ALT, AST and sCr, significantly increased within $180 \mathrm{~min}$, while BUN and AMY were not influenced at any time (Table 4).

\section{Discussion}

C. capillata, a relatively mild toxic jellyfish in comparison to Chironex fleckeri or Physalia physalis, is a common species of the coast of China [10]. Therefore, the clinical manifestations of $C$. capillata envenomation and physiopathologic research on this venom have a particular significance in China. In the present study, we aimed to explore the activities besides hemolytic [5] and cardiovascular [6,7] 
toxicities of $C$. capillata venom by observing the toxic symptoms and hematological changes caused by TOE.

Table 4. Effects of TOE from the jellyfish $C$. capillata on biochemical indexes in anesthetized

$\mathrm{SD}$ rats. Data are presented as means $\pm \mathrm{SD}(n=6, * P<0.05, * * P<0.01 v s .0 \mathrm{~min})$.

\begin{tabular}{ccccccccc}
\hline & LDH $(\mathbf{U} / \mathbf{L})$ & CK $(\mathbf{U} / \mathbf{L})$ & CK-MB $(\mathbf{U} / \mathbf{L})$ & ALT $(\mathbf{U} / \mathbf{L})$ & AST $(\mathbf{U} / \mathbf{L})$ & sCr $(\boldsymbol{\mu m o l} / \mathbf{L})$ & BUN $(\mathbf{m m o l} / \mathbf{L})$ & AMY $(\mathbf{U} / \mathbf{L})$ \\
\hline $0 \mathrm{~min}$ & $695 \pm 187$ & $649 \pm 393$ & $1067 \pm 227$ & $46 \pm 8$ & $114 \pm 55$ & $22 \pm 4$ & $5.1 \pm 1.0$ & $1946 \pm 254$ \\
$5 \mathrm{~min}$ & $692 \pm 295$ & $987 \pm 588$ & $1211 \pm 303$ & $59 \pm 13$ & $157 \pm 33$ & $25 \pm 11$ & $6.3 \pm 1.3$ & $2021 \pm 581$ \\
$10 \mathrm{~min}$ & $718 \pm 358$ & $1113 \pm 539$ & $1574 \pm 456 *$ & $56 \pm 20$ & $154 \pm 53$ & $29 \pm 9$ & $6.0 \pm 1.7$ & $2099 \pm 494$ \\
$20 \mathrm{~min}$ & $760 \pm 496$ & $1192 \pm 697$ & $1826 \pm 616 *$ & $68 \pm 19 *$ & $185 \pm 80$ & $28 \pm 4 *$ & $6.7 \pm 1.5$ & $2343 \pm 393$ \\
$60 \mathrm{~min}$ & $3171 \pm 4422$ & $2085 \pm 2782$ & $1889 \pm 607 *$ & $166 \pm 235$ & $362 \pm 372$ & $36 \pm 9 * *$ & $5.1 \pm 1.6$ & $2070 \pm 342$ \\
$180 \mathrm{~min}$ & $5816 \pm 5335 *$ & $2231 \pm 1212 *$ & $2772 \pm 885 *$ & $354 \pm 257 *$ & $785 \pm 201 * *$ & $57 \pm 19 * *$ & $6.8 \pm 1.8$ & $1913 \pm 664$ \\
\hline
\end{tabular}

At first, the acute toxicity of TOE was determined in mice by tail vein injection, and the $\mathrm{LD}_{50}$ was calculated as $4.25 \mathrm{mg} / \mathrm{kg}$. During the $\mathrm{LD}_{50}$ determination, we observed that the toxic symptoms were dose-dependent, so we divided the doses into three grades according to the toxic symptoms (Table 1). In the lower dose grade (less than $5 \mathrm{mg} / \mathrm{kg}$ ), the mice mainly showed heart failure-related symptoms, including congestion and edema in lung and edema in heart. In the highest dose grade (more than $10 \mathrm{mg} / \mathrm{kg}$ ), the mice mainly showed typical central nervous system-related symptoms, including body trembling, double leg twitching, convulsion and opisthotonos. In the intermediate dose grade $(5-10 \mathrm{mg} / \mathrm{kg})$, the mice showed heart failure and nervous system-related symptoms simultaneously. In light of this, we speculate that the TOE may have strong and acute neurotoxicity in addition to its cardiovascular toxicity, leading to rapid death at high doses.

Among the arterial blood gas indexes, $\mathrm{pH}, \mathrm{PO}_{2}$ and $\mathrm{PCO}_{2}$ showed irreversible changes beginning quickly after TOE administration at the dose of $5 \mathrm{mg} / \mathrm{kg}$ i.v., and other indexes, including $\mathrm{HCO}_{3}{ }^{-}$, $\mathrm{HCO}_{3}$ std, $\mathrm{TCO}_{2}$, BEecf and $\mathrm{BE}(\mathrm{B})$, decreased significantly within $5 \mathrm{~min}$, suggesting that metabolic acidosis developed quickly, which might be attributed to a direct and severe hemolytic reaction that led to the release of both lactic acid and $\mathrm{K}^{+}$. Eventually, $\mathrm{PCO}_{2}$ decreased because of compensatory hyperpnea, but $\mathrm{PO}_{2}$ and $\mathrm{SO}_{2} \mathrm{c}(\%)$ did not decrease until rat death, suggesting that the respiratory response is not the major cause of death by TOE.

After TOE administration, $\mathrm{Na}^{+}$and $\mathrm{Ca}^{2+}$ decreased rapidly, but $\mathrm{K}^{+}$increased and reached a maximum at $5 \mathrm{~min}$. These responses could be easily attributed to the severe hemolysis of TOE in vivo, which induces intracellular lactic acid and $\mathrm{K}^{+}$release. However, the hemolysis of TOE in vivo may not be the only mechanism underlying electrolyte changes. Nematocyst venom from $P$. physalis markedly increases $\mathrm{Ca}^{2+}$ influx, $\mathrm{Na}^{+}$influx and $\mathrm{K}^{+}$efflux in a dose-dependent manner in cultured embryonic chick heart cells [11]. Another study [12] found that $P$. physalis nematocyst venom can induce $\mathrm{Ca}^{2+}$ influx into various kinds of cells, which are not limited to those from the cardiovascular system. P. physalis venom produces pore-like structures in intact cultured cells [13]. All of these results indicate that TOE may decrease circulating $\mathrm{Ca}^{2+}$ and $\mathrm{Na}^{+}$and increase $\mathrm{K}^{+}$by stimulating cellular $\mathrm{Ca}^{2+}$ and $\mathrm{Na}^{+}$influx and $\mathrm{K}^{+}$ efflux through pores created in the cell membrane.

In this study, the elevation of all examined heart injury-related enzymes, including LDH, CK, CK-MB and AST, further indicated that direct cardiac toxicity is the leading cause of death and that a cardiac depressive response is the basic physiopathologic change caused by TOE in anesthetized 
rats [8]. Moreover, AST and ALT significantly increased, indicating that liver function might be influenced by TOE in vivo. Preliminary in vitro studies have shown that jellyfish nematocyst venoms are extremely toxic to hepatocytes by inhibiting their metabolic activities [14,15], which is consistent with our in vivo results with TOE from $C$. capillata. However, it should be noted that acute liver congestion, which could have resulted from acute total heart failure, may also have contributed to the elevation of AST and ALT. sCr markedly increased, but BUN remained normal. In addition, we have reported the negative results of kidney pathological examinations previously [8]. Thus, these results indicate that the kidney might function normally at least $3 \mathrm{~h}$ after TOE administration. The $\mathrm{sCr}$ elevation may suggest that TOE has muscular toxicity, but our data do not allow us to distinguish whether the sCr elevation was simply due to cardiac muscle injury or both skeletal muscle and cardiac muscle injuries.

Blood glucose had an initial transient rise and then lowered to the normal level gradually within 180 min. Nemocyst venom from the "Irukandji" jellyfish Alatina $n r$ mordens can cause marked increases of plasma epinephrine and norepinephrine in anesthetized rats [16], so we presume that the fluctuation of glucose level could be attributed to catecholamines or components contributing to release of endogenous catecholamines. Similarly, the initial pressor responses caused by $C$. fleckeri and C. barnesi venoms are also attributed to the over-release of endogenous catecholamines in rats $[17,18]$. Mature erythrocytes of mammals have no mitochondria, so glycolysis is their only glucose utilization pathway. In this study, the quickly increased lactic acid might be explained as the consequence of hemolysis induced by TOE. On the other hand, lactic acid elevation can result in a $\mathrm{pH}$ decrease, metabolic acidosis and $\mathrm{K}^{+}$elevation. After TOE administration, hemodiastase did not significantly increase, suggesting that pancreatic function remained normal. Hct\% and THbc showed an initial increase, then a quick recovery, indicating that hypovolemic shock, characterized by loss of numerous extracellular fluids, was not the reason for hypotension caused by TOE in vivo.

\section{Experimental Section}

\subsection{TOE Preparation from the Jellyfish C. capillata}

Specimens of $C$. capillata were collected in July 2009 on the Sanmenwan coast of the East China Sea in Zhejiang Province, China. The removed tentacles were preserved in plastic bags on dry ice and immediately shipped to Shanghai, where the samples were frozen at $-70{ }^{\circ} \mathrm{C}$ until use. The TOE devoid of nematocysts was prepared following the method described by us and other authors [7,19]. Briefly, frozen tentacles were thawed at $4{ }^{\circ} \mathrm{C}$ and immersed in filtered seawater at the mass:volume ratio of $1: 1$ to allow autolysis of the tissues for 4 days. The mixture was stirred for $30 \mathrm{~min}$ twice daily. The autolyzed mixture was centrifuged at $10,000 \times g$ for $15 \mathrm{~min}$ thrice. The resultant supernatant was the TOE.

All procedures were performed at $4{ }^{\circ} \mathrm{C}$ or in an ice bath. Before being used for injection, the TOE was centrifuged at $10,000 \times \mathrm{g}$ for $15 \mathrm{~min}$ to remove the sediments, followed by dialysis against PBS $(0.01 \mathrm{~mol} / \mathrm{L}, \mathrm{pH} 7.4)$ for over $8 \mathrm{~h}$. The protein concentration in the preparations was determined with the Bradford method [20], with fetal bovine serum as the standard. 


\section{2. $L D_{50}$ Determination and Toxic Symptom}

Kunming mice (17-22 g, provided by the Laboratory Animal Center of the Second Military Medical University, Shanghai) were randomized into 10 groups $(n=12)$ for TOE administration by tail vein injection (the same injection volume at $0.1 \mathrm{~mL}$ per $10 \mathrm{~g}$ body weight, with different TOE concentrations). The dose ratio between the adjacent groups was 0.8 . After TOE administration, the toxic symptoms were monitored for one week, and the numbers of both surviving and dead mice were recorded. The median lethal dose $\left(\mathrm{LD}_{50}\right)$ was calculated using Karber's method [21]. All animal experiments were approved by the Ethics Committee of the Second Military Medical University.

\subsection{Hematological Indexes Determined by an Arterial Blood Gas Analyzer}

Male SD rats $(220 \pm 20 \mathrm{~g}$, provided by the Laboratory Animal Center of the Second Military Medical University, Shanghai) were anesthetized with urethane (1.2 g/kg i.p.). Tracheotomy was performed to make the spontaneous ventilation easier. A heparinized catheter was inserted into the external jugular vein for intravenous administration of TOE $(5 \mathrm{mg} / \mathrm{kg})$. An arterial blood sample was drawn through a catheter that was inserted into the left femoral artery by a heparinized syringe. Afterwards, the syringe was sealed quickly with a rubber stopper. Hematological indexes, including blood gases (direct indexes: $\mathrm{pH}, \mathrm{PCO}_{2}$ and $\mathrm{PO}_{2}$; indirect indexes: $\mathrm{HCO}_{3}{ }^{-}, \mathrm{HCO}_{3}$ std, $\mathrm{TCO}_{2}, \mathrm{BEecf}, \mathrm{BE}(\mathrm{B})$ and $\mathrm{SO}_{2} \mathrm{c}(\%)$ ), electrolytes $\left(\mathrm{Na}^{+}, \mathrm{K}^{+}\right.$and $\mathrm{Ca}^{2+}$ ), hematocrit (Hct), glucose (Glu) and lactic acid (Lac), were measured within $30 \mathrm{~min}$ by an arterial blood gas analyzer (GEM Premier 3000, International Laboratory, USA). Measurements were divided into six groups: 0 (pre-administration), 5, 10, 20, 60 and 180 min after administration of $5 \mathrm{mg} / \mathrm{kg}$ TOE.

\subsection{Hematological Indexes Determined by an Automatic Biochemistry Analyzer}

Arterial blood samples, which were acquired as described in Section 2.3, were centrifuged at $3000 \times g$ for $15 \mathrm{~min}$, and the supernatant was collected as the serum, which was analyzed by an automatic biochemistry analyzer (AIRONE-200puls, Crony Company, Italy). Hematological indexes, including lactate dehydrogenase ( $\mathrm{LDH})$, creatine kinase (CK), MB isoenzyme of creatine kinase (CK-MB), alanine aminotransferase (ALT), aspartate aminotransferase (AST), serum creatinine ( $\mathrm{sCr}$ ), blood urea nitrogen (BUN) and hemodiastase (AMY), were measured. Measurements were divided into six groups: 0 (pre-administration), 5, 10, 20, 60 and $180 \mathrm{~min}$ after administration of $5 \mathrm{mg} / \mathrm{kg}$ TOE.

\subsection{Data Analysis}

One-way analysis of variance (ANOVA) was used. In all cases, statistical significance was indicated by $P<0.05$. All quantitative data are expressed as means \pm SD.

\section{Conclusions}

The present study on the toxic symptoms and hematological changes induced by TOE advances our understanding of the in vivo pathophysiological effects of jellyfish envenomation. In addition to 
hemolytic and cardiovascular toxicities, TOE from C. capillata may also exhibit neurotoxicity, liver toxicity and muscular toxicity, but no kidney or pancreatic toxicity.

\section{Acknowledgments}

This research was funded by the National Natural Science Foundation Young Scientists Fund (81000098), the Natural Science Foundation of Shanghai Municipal Government (10ZR1437900) and the Foundation of the "Eleventh Five-Year Plan" for Medical Science Development of PLA (06Z020).

\section{References}

1. Burnett, J.W. Medical aspects of jellyfish envenomation, pathogenesis, case reporting and therapy. Hydrobiologia 2001, 451, 1-9.

2. Tibballs, J. Australian venomous jellyfish, envenomation syndromes, toxins and therapy. Toxicon 2006, 48, 830-859.

3. Brinkman, D.L.; Burnell, J.N. Biochemical and molecular characterization of cubozoan protein toxins. Toxicon 2009, 54, 1162-1173.

4. Suput, D. In vivo effects of cnidarian toxins and venoms. Toxicon 2009, 54, 1190-1200.

5. Nie, F.; Xiao, L.; Zhang, J.; He, Q.; Fan, J.W.; Li, Y.; Zhang, L.M. Comparison of haemolytic activities of venom separations from jellyfish Cyanea capillata and their influencing factors. Acad. J. Sec. Mil. Med. Univ. 2008, 29, 83-86.

6. Xiao, L.; Guo, Y.F.; Zhang, J.; He, Q.; Nie, F.; Li, Y.; Ye, X.F.; Zhang, L.M. Bioactive analysis of tentacle-only extract from jellyfish Cyanea capillata. Chin. J. Mar. Drugs 2008, 27, 23-27.

7. Xiao, L.; He, Q.; Guo, Y.F.; Zhang, J.; Nie, F.; Li, Y.; Ye, X.F.; Zhang, L.M. Cyanea capillata tentacle-only extract as a potential alternative of nematocyst venom: Its cardiovascular toxicity and tolerance to isolation and purification procedures. Toxicon 2009, 53, 146-152.

8. Xiao, L.; Liu, G.S.; Wang, Q.Q.; He, Q.; Liu, S.H.; Li, Y.; Zhang, J.; Zhang, L.M. The lethality of tentacle-only extract from jellyfish Cyanea capillata is primarily attributed to cardiotoxicity in anaesthetized SD rats. Toxicon 2010, 55, 838-845.

9. Xiao, L.; Zhang, J.; Wang, Q.; He, Q.; Liu, S.; Li, Y.; Zhang, L. In vitro and in vivo haemolytic studies of tentacle-only extract from jellyfish Cyanea capillata. Toxicol. in Vitro 2010, 24, 1203-1207.

10. Ge, L.J.; He, D.M. The marking signal of ecosystem crisis. China Fish. 2004, 9, 23-25.

11. Edwards, L.; Luo, E.; Hall, R.; Gonzalez, R.R.; Hessinger, D.A. The effect of Portuguese Man-of-war (Physalia physalis) venom on calcium, sodium and potassium fluxes of cultured embryonic chick heart cells. Toxicon 2000, 38, 323-335.

12. Edwards, L.; Hessinger, D.A. Portuguese Man-of-war (Physalia physalis) venom induces calcium influx into cells by permeabilizing plasma membranes. Toxicon 2000, 38, 1015-1028.

13. Edwards, L.P.; Whitter, E.; Hessinger, D.A. Apparent membrane pore-formation by Portuguese Man-of-war (Physalia physalis) venom in intact cultured cells. Toxicon 2002, 40, 1299-1305.

14. Houck, H.E.; Lipsky, M.M.; Marzella, L.; Burnett, J.W. Toxicity of sea nettle (Chrysaora quinquecirrha) fishing tentacle nematocyst venom in cultured rat hepatocytes. Toxicon 1996, 34, 771-778. 
15. Cao, C.J.; Eldefrawi, M.E.; Eldefrawi, A.T.; Burnett, J.W.; Mioduszewski, R.J.; Menking, D.E.; Valdes, J.J. Toxicity of sea nettle toxin to human hepatocytes and the protective effects of phosphorylating and alkylating agents. Toxicon 1998, 36, 269-281.

16. Winter, K.L.; Isbister, G.K.; Schneider, J.J.; Konstantakopoulos, N.; Seymour, J.E.; Hodgson, W.C. An examination of the cardiovascular effects of an 'Irukandji' jellyfish, Alatina nr mordens. Toxicol. Lett. 2008, 179, 118-123.

17. Ramasamy, S.; Isbister, G.K.; Seymour, J.E.; Hodgson, W.C. Pharmacologically distinct cardiovascular effects of box jellyfish (Chironex fleckeri) venom and a tentacle-only extract in rats. Toxicol. Lett. 2005, 155, 219-226.

18. Ramasamy, S.; Isbister, G.K.; Seymour, J.E.; Hodgson, W.C. The in vivo cardiovascular effects of the Irukandji jellyfish (Carukia barnesi) nematocyst venom and a tentacle extract in rats. Toxicol. Lett. 2005, 155, 135-141.

19. Bloom, D.A.; Burnett, J.W.; Alderslade, P. Partial purification of box jellyfish (Chironex fleckeri) nematocyst venom isolated at the beachside. Toxicon 1998, 36, 1075-1085.

20. Bradford, M.M. A rapid and sensitive method for the quantitation of microgram quantities of protein utilizing the principle of protein dye binding. Anal. Biochem. 1976, 72, 248-254.

21. El-Sayed, Y.S.; Khalil, R.H.; Saad, T.T. Acute toxicity of ochratoxin-A in marine water-reared sea bass (Dicentrarchus labrax L.). Chemosphere 2009, 75, 878-882.

Sample Availability: Available upon request.

(C) 2011 by the authors; licensee MDPI, Basel, Switzerland. This article is an open access article distributed under the terms and conditions of the Creative Commons Attribution license (http://creativecommons.org/licenses/by/3.0/). 